dilute solutions and showed that their results were in agreement with the ionic theory which Arrhenius had recently put forward. As a result of these studies he published in 1902 his book "The Theory of Solution", which was for a time the standard textbook on the subject.

In 1891 Dampier was elected to the fellowship at Trinity College, Cambridge, which he retained until the end of his life. After serving for some years as a College lecturer, he accepted the heavy duties of a College tutorship. In this office he showed a capacity for human sympathy which his many pupils gratefully remember; but his duties took up so much of his time that he had to drop his laboratory work. His mind, however, was very active. During this period he published books on eugenies and was collecting material for his "History of Science" (1929).

Meanwhile, with his love of the country and country pursuits, Dampier could not be satisfied with life spent entirely in Cambridge. $\mathrm{He}$ and his wife bought an estate in Devonshire, and problems connected with agricultural economics soon forced themselves on his attention. In 1917 he inherited a small family estate. At that time he was working parttime with Sir Thomas Middleton at the Food Production Department of the Ministry of Agriculture. $\mathrm{He}$ characteristically decided to put his agricultural ideas to the test by taking two farms near his estate and operating them through a manager. The scarcity of cheese during the First World War directed his attention to this product, and he set up a small cheese factory in connexion with his farms. Here the problem of using the surplus whey led him to experiments in the production of lactose, which eventually developed into a process used on a commercial scale.

The falling prices from 1920 onwards focused Dampier's attention on the relationship between money, prices and agricultural profits. He published his opinions on these subjects in the Economic Journal (1925) and in a book, "Politics and the Land" (1927).

The interest aroused by these publications and the reputation for sound judgment which Dampier had acquired in several forms of public service led to his being consulted by the Government on many problems of agricultural policy. Of these none was more important than those which led to the formation of the Agricultural Research Council. After the First World War, when it became clear that the Government would have to spend large sums in supporting scientific and medical research, the Department of Scientific and Industrial Research and the Medical Research Council were set up to encourage and regulate government expenditure and activity in these fields. No such body existed for agricultural science; but 2 number of laboratories devoted to agricultural research were being largely supported through public funds. Since these independent bodies were in some cases absorbing increasingly large grants, it became clear to the authorities that a body analogous to the Department of Scientific and Industrial Research or the Medical Research Council would have to be set up for agriculture. Dampier's tact and experience were of great value during the delicate negotiations which were necessary to bring the existing independent bodies into a state of mind favourable for setting up an Agricultural Research Council which would regulate their grants. Dampier became the secretary to the Council, and guided it in the difficult early stages until it became firmly established. He also took great interest in rural community councils.

Dampier was elected to the Royal Society in 1901, was knighted in 1931 and awarded the Gold Medal of the Royal Agricultural Society in 1936. He married Catherine Holt in 1897 and had five daughters. His loss will bo deeply felt in Trinity College, to which he was so devoted and gave such good service.

G. I. TAYLOR

\section{Prof. L. B. Smyth}

Louis Bouvier SMYtH was born in Dublin in 1883 and died there on July 11, 1952. His father was Mr. Isaac Smyth of Dublin; his mother was French. He received his school education at Wesley College, Dublin, and entered Trinity College in 1902. He graduated in 1906, obtaining senior moderatorship in natural science with a large gold medal, awarded for first place on exceptionally high marks. In those days candidates took botany, geology and zoology, equal weight being assigned to each course during the four years; but for the degree a special course also had to be taken in one subject. Smyth took botany and was appointed as assistant to Prof. H. H. Dixon during the period when the present School of Botany was being built and the department organized. This happy collaboration continued for three years. He then accepted a post as naturalist in the Fisheries Branch of the Department of Agriculture and took part in several cruises to study, in particular, the phytoplankton. After a year there he was invited by Prof. John Joly to join his staff, and from 1911 until his death he continued in the Iveagh Geological Laboratory at Trinity College, Dublin. In 1911 also he married, very happily. He is survived by his widow.

Joly sent Smyth to work in Oxford under the late Dr. Arthur Vaughan, the leading English palæontologist of that period, and, on his return to Dublin, Smyth was appointed lecturer in palæontology. Then for more than twenty years he did all the exclusively honours teaching in the Geological Department in mineralogy, petrology, palæontology and geological map-reading. Sometimes also he had to lecture as Joly's deputy, and in six consecutive years he had the Senior Engineering Class on ore deposits. From 1931 until 1934 he occupied also the newly made post of lecturer in geography.

But Smyth's influence in Trinity College, Dublin, extended far beyond the geological laboratories. He joined the O.T.C. when it was first started, and was commissioned. $\mathrm{H}_{e}$ was in the Territorial Forces (Unattached List) in January 1915 and was promoted lieutenant 1916; but a disabling affliction denied him his wish of going on active service. The value of his military work may be realized on looking at the T.C.D. War List (1922); the total trained by the Corps was 1,490, with some 3,000 members of the University serving, and more than 460 names on the walls of the Hall of Honour. On committees too his quiet business-like manner and precision were of much volue; most notable was his service as secretary of the University Council, and on the Board of Trinity College in his last years.

His first published work (1911) was with Joly, on the radium emanation in the soil. The rest were almost all in his sole name and appeared mainly in the Scientific Proceedings of the Royal Dublin Society, the Proceedings of the Royal Irish Academy, the Geological Magazine and the Quarterly Journal of the 
Geological Society of London. In these the patient examination of the strata and the marshalling of the palæontological evidence linked up the geology of North Wales and the Irish coast. The first of the series dealt with the faunal zones of the RushSkerries Carboniferous Section, Co. Dublin, and further papers considered the strata at Malahide and at Ballycastle, Co. Antrim. The fine paper on the geology of Great Orme's Head (1925) led to the award of the Sc.D. degree. The Irish Academy published a similar contribution on the Carboniferous Rocks of Hook Head, Co. Wexford (1930). His papers gave detailed descriptions of fossils, notably of corals.

In 1934 Smyth succeeded Joly in the University chair of geology, which he occupied until his death. He devoted himself, unremittingly, to his teaching, and to the improvement of the Geological Museum and Department. $\mathrm{He}$ was never happier than when taking his students and overseas colleagues on geological expeditions-and few university cities have more varied geological interest close at hand than has Dublin. After a gap, occasioned by his teaching duties and illnesses, came "The Carboniferous System of North County Dublin" (Geol. Soc., 1950) and "A Viséan Cephalopod Fauna in the Rush Slates" (Roy. Irish Acad., 1951). A clear lecturer, a sympathetic teacher, loyally devoted to his University, a true friend - there are many who mourn his loss. W. R. G. Atkrins

\section{Mr. C. E. N. Bromehead}

Cyril Edward Nowill Bromehtad, formerly of the Geological Survey, died on December 4. He was born at York on January 8, 1885, and was educated at Marlborough and at Merton College, Oxford. $\mathrm{He}$ joined the Geological Survey of Great Britain in 1909 and was assigned as his first major task the 6-inch survey of a large part of the London area. With Henry Dewey he devised the present nomenclature of the gravel-terraces of the Thames Valley, and he became an authority on the geology and early history of London and particularly on the buried tributaries of the Thames such as the Fleet and Ty Bourne.

In the First World War he served in Flanders and was severely wounded. He returned to the Geological Survey in time to take part in explorations in Derbyshire which led in 1919 to the drilling of Britain's first oil-well at Hardstoft.

In 1922 he was appointed district geologist in charge of Yorkshire. Employing techniques of stratigraphical palæontology then being devised by W. S. Bisat, Sir Arthur Trueman and W. B. Wright, he and his staff became experts on the Upper Carboniferous rocks. In fifteen years his unit made a detailed revision of most of the coalfield and its borders-an area of nearly 1,000 square miles-and sent to the press the relevant maps and memoirs as well as a new edition of the memoir on the "Concealed Coalfield of Yorkshire and Nottinghamshire". These publications have proved invaluable in subsequent developments of the coalfield.

In 1935 Bromehead took charge of geological work in Southern England, where mapping was proceeding in Kent. For much of the next ten years, however, his duties were connected with the Second World War, and throughout this time his knowledge and experience were always at his colleagues' service. $\mathrm{He}$ relinquished some of his responsibilities in 1945 and retired in 1949 .
During this last period his interest in the origins of geology and related arts (he-was a founder-member of the Society for History of Science) was revealed in two presidential addresses to the Geologists' Association on the early history of practical geology and mining in Britain, and in papers on antiquarian subjects-'eagle-stones', loadstones, 'murrhine', early water-supply and museums - in which a high order of classical scholarship was delightfully blended with geology. He also wrote on oil, reservoir-dams and fluorosis.

Profoundly influenced in his youth by what was then known as the 'Oxford Movement', Bromehead practised religion with characteristic thoroughness. $\mathrm{He}$ is remembered with affection by the many who experienced his kindliness and culture, his wisdom and, not least, his firmness in moments of crisis.

WILFRID EDWARDS

\section{Mr. R. S. Styles and Mr. F. W. Campbell}

Ronald Stephen Styras and Frederick William Campbell, who were attached to the Division of Radiophysics of the Commonwealth Scientific and Industrial Research Organization, Australia, were killed in an aircraft accident near Sydney on October 27 while engaged on research in cloud physics and natural rain formation.

Styles and Campbell were on a routine flight in an R.A.A.F. Dakota fitted for cloud 'probing' using microwave radar and special instruments designed in the Division of Radiophysics for observing cloud temperature, liquid-water content and cloud droplet spectra. The aireraft had been investigating clouds over the sea and reported that it was descending from $6,000 \mathrm{ft}$. to $2,000 \mathrm{ft}$. through low cloud and heavy rain preparatory to returning to base. It failed to report at the next check-point, and an intensive emergency search was immediately organized. Oil, wreckage and a half-inflated rubber dinghy were found a short distance out to sea, and some items recovered were identified as belonging to personnel on the aircraft; all on board, including an R.A.A.F. crew of four, were killed.

Mr. Styles was born in Sydney, Now South Wales, in 1926. At the University of Sydney he took a course combining physics and electrical engineering. $\mathrm{He}$ graduated with the double degree of B.Sc. and B.E. and joined the Radiophysics Division as a research officer in March 1948. His initial work concerned radio aids to aircraft navigation, to which he made valuable contributions. He was then transferred to work on rain and cloud physics, and his obvious ability and enthusiasm soon led to his taking a major part in airborne observations of natural rain. His observations of the development of non-freezing clouds to give rain are of particular interest. He also contributed significantly to the development of instruments in this field and displayed a marked ability for organizing, implementing and analysing results in this difficult field of research. He leaves a widow and an infant son.

Mr. Campbell was born in 1915, at Norseman, Western Australia. After successfully completing a radio course at Perth Technical College in 1934, he spent the pre-war years as a radio engineer in Perth. During the Second World War he served with the Royal Air Force, rising to the rank of squadron leader. $\mathrm{He}$ undertook specialized radio and radar courses at Prestwick, Great Malvern and elsewhere, 